\title{
Faktor-Faktor Psikologis sebagai Determinan Kepatuhan Pajak: Studi Eksplorasi pada Wajib Pajak
}

\author{
Elis Anisah Fitriah ${ }^{1}$, Zulrizka Iskandar $^{2}$, Wilis Srisayekti ${ }^{3}$, Zainal Abidin ${ }^{4}$ \\ Fakultas Psikologi, Universitas Islam Negeri Sunan Gunung Djati Bandung, Indonesia ${ }^{1}$ \\ Fakultas Psikologi, Universitas Padjadjaran, Indonesia ${ }^{1,2,3,4}$ \\ e-mail: elis.anisah@uinsgd.ac.id ${ }^{1}$
}

\begin{abstract}
This study aimed to explore the cognition of taxpayers related to their experience in reporting income tax and understand what the influencing factors on the willingness to pay taxes. Interpretative phenomenology design was applied through semi-structured interviews to four taxpayers as participants. Data was analyzed by developing of textures and structural descriptions. The results showed that psychological factors that considered by participant in their tax behavior including knowledge about the system and tax regulation as well as information on the use of tax returns; perceived service and trust in tax authority. Further research is needed to understand the dynamics of psychological variables in influencing tax behavior with cooperative perspective instead of compliance to avoid punishment.
\end{abstract}

Keywords: income tax, tax behavior, information, service, public trust

\begin{abstract}
Abstrak
Penelitian ini bertujuan untuk memperoleh pemaknaan wajib pajak terkait pembayaran pajak penghasilan yang dilakukannya serta memahami faktor apa saja yang memengaruhi kesediaan wajib pajak melakukan pembayaran pajak. Rancangan fenomenologi interpretatif digunakan terhadap empat orang wajib pajak, data dikumpulkan melalui semi-structured interview dan dianalisis dengan mengembangkan deskripsi tekstur serta deskripsi struktural dari pemaknaan partisipan. Hasilnya menunjukkan bahwa faktor-faktor psikologis yang berperan dalam perilaku pajak partisipan antara lain pengetahuan tentang sistem dan aturan pajak serta informasi terkait pemanfaatan hasil pajak; persepsi layanan dari otoritas pajak; dan kepercayaan terhadap otoritas pajak. Perlu dilakukan penelitian lanjutan untuk memahami dinamika variabel-variabel psikologis dalam memengaruhi perilaku pajak dalam perspektif kooperatif dari sekedar kepatuhan untuk menghindari hukuman.
\end{abstract}

Kata Kunci: pajak penghasilan, perilaku pajak, informasi, layanan, kepercayaan publik

\section{Pendahuluan}

Pajak merupakan sumber pendanaan terbesar negara untuk melaksanakan pembangunan nasional di Indonesia yang menyumbang sekitar lebih dari $70 \%$ dari seluruh penerimaan negara. Penggunaan pajak meliputi pembangunan infrastruktur, biaya pendidikan, biaya kesehatan, subsidi bahan bakar minyak (BBM), gaji aparatur sipil negara dan pembangunan fasilitas publik. Menurut Undang-undang Nomor 28 tahun 2007, Pajak adalah kontribusi wajib kepada negara yang terutang oleh orang pribadi atau badan yang bersifat memaksa berdasarkan Undang-Undang, dengan tidak mendapatkan imbalan secara langsung dan digunakan untuk keperluan negara bagi sebesar-besarnya kemakmuran rakyat (diakses dari www.dpr.go.id).

Perpajakan di Indonesia dibangun pada prinsip kegotongroyongan. Namun dalam kenyataannya rasio pajak Indonesia berada pada kisaran $10.3 \%$ dari target sekitar 16\%. Angka ini lebih rendah dibandingkan dengan Malaysia dan Singapura yang rasio pajaknya berada di atas 13\% (diakses dari tempo.co). 
Indonesia menganut self-assessment system sejak 1984 yang memberi kepercayaan kepada wajib pajak untuk menentukan sendiri besarnya pajak yang terutang. Cirinya adalah wajib pajak aktif menghitung, menyetor dan melaporkan sendiri pajaknya, sedangkan otoritas pajak berperan dalam melakukan fungsi pengawasan (Mardiasmo, 2011). Keberhasilan metode ini sangat bergantung pada kesadaran dan peran serta masyarakat untuk membayar pajaknya.

Upaya pemerintah untuk mendorong penerimaan pajak terus dilakukan namun jumlah wajib pajak yang membayar masih sedikit dan yang menghindari pajak masih tinggi. Dari 257 juta penduduk Indonesia, pada April 2018 yang teregistrasi membayar pajak hanya 38.7 juta, dan yang membayar pajak hanya 10.6 juta orang (detikfinance//m.detik.com/16 Mei 2018). Pada April 2019, terdapat kenaikan sekitar 6.6 persen dari tahun 2018, namun angka kepatuhan masih di bawah target yang ditetapkan pemerintah. Direktorat Jenderal Pajak mencatat dari 15.85 juta target wajib pajak yang harus melapor, hanya 11.309 juta yang melaporkan Surat Pemberitahuan Tahunan (SPT) Pajak Penghasilan tahun ini (diakses dari www.cnnindonesia.com, 2 April 2019).

Masih rendahnya rasio pajak dari target yang ditetapkan diduga karena masih rendahnya kepatuhan masyarakat terkait pajak. Kepatuhan pajak merupakan kondisi di mana wajib pajak secara sukarela ataupun terpaksa membayar kewajiban pajak dengan benar dan tepat waktu.

Persoalan mengenai pembayaran pajak merupakan suatu situasi dilema sosial dimana terjadinya konflik antara kepentingan pribadi dan kepentingan umum/ kolektif. Di satu sisi, wajib pajak ingin memperoleh pendapatan personal yang maksimal dengan menghindari atau mengurangi jumlah nilai pajak yang seharusnya, namun di sisi lain, pajak yang dibayarkan kepada negara akan digunakan untuk membiayai berbagai kepentingan publik. Jika sebagian besar individu memilih untuk mementingkan kepentingan personalnya maka akan mengakibatkan kerugian bagi kelompoknya maupun dirinya sendiri pada jangka panjang (Dawes, 1980; Van Lange, Balliet, Parks, \& Van Vugt, 2014). Pajak merupakan dilema public goods yang menuntut individu-individu untuk menyumbang atau membayar sejumlah tertentu yang mengurangi pendapatannya agar terakumulasi sehingga dapat membiayai berbagai barang dan layanan publik yang dapat digunakan semua orang secara bersamasama (Parks, Joireman, \& Van Lange, 2013).

Berbagai studi dilakukan untuk meneliti bagaimana kepatuhan wajib pajak dapat ditingkatkan sehingga barang dan layanan publik dapat didanai secara memadai agar kesejahteraan umum dapat tercapai. Pada awal perkembangan penelitian mengenai pajak, pendekatan ekonomi lebih digunakan. Pendekatan ini berpendapat bahwa membayar pajak sebagai keputusan ekonomis individual dalam kondisi berisiko karena adanya audit dan denda yang tinggi dari otoritas pajak sebagai wakil pemerintah. Kejujuran pajak meningkat dengan probabilitas audit yang lebih tinggi dan denda yang lebih berat (Allingham \& Sandmo, 1972; Becker, 1968; Alm, Sanchez, \& De Juan, 1995). Namun demikian audit dan sanksi tidak memiliki efek jangka panjang terhadap kesediaan membayar pajak antara lain berkaitan dengan pengalaman yang dipelajari terhadap kemungkinan audit (Mittone, 2006) maupun jeda waktu antar audit yang cenderung membuat subjek memersepsi peluang untuk memperbaiki kehilangan pasca audit (Maciejovsky, Kirchler, \& Schwarzenberger, 2007).

Pertimbangan bahwa keputusan membayar pajak dengan pendekatan hukuman adalah sesuatu yang kompleks, berdampak pada perkembangan penelitian dengan perspektif yang berbeda mengenai perilaku pajak yang tidak bisa dijelaskan 
dengan pendekatan ekonomi semata. Kontribusi dari berbagai disiplin ilmu telah menunjukkan pentingnya interaksi antara insentif moneter yang menegakkan kepatuhan dan prinsip normatif yang mendorong kooperatif yang bersifat sukarela terkait keputusan kepatuhan pajak. Para psikolog menyarankan bahwa kepatuhan sukarela dan kooperatif dengan administrasi pajak dapat dipupuk oleh trust dan legitimasi kekuasaan pihak berwenang, sehingga dapat mengurangi kebutuhan pemantauan yang mahal (Hofmann, Hartl, Gangl, Tiefenthaler, \& Kirchler 2017; Kirchler, 2007; Kirchler, Hoelzl, \& Wahl, 2008; Kogler, Batrancea, Nichita, Pantya, Belianin, \& Kirchler, 2013). Kesediaan untuk membayar pajak juga meningkat ketika wajib pajak memiliki kesadaran dan pengetahuan tentang undang-undang dan aturan pajak (Alm, 2012) serta memiliki postur motivasional positif berupa komitmen moral untuk berkontribusi pada masyarakat (Braithwaite, 2003). Feld dan Frey (2007) menunjukkan pentingnya hubungan antara pembayar pajak dan otoritas pajak yang menekankan pada mutual respek sehingga meningkatkan tingkat kepatuhan pajak.

Dalam perspektif lintas budaya, kajian tentang perilaku membayar pajak juga banyak diteliti. Hyun (2006) menyelidiki perbedaan kepatuhan antara Korea Selatan dan Jepang dan menemukan bahwa budaya pajak merupakan salah satu penentu mendasar dari perbedaan ini, yang mana Jepang memiliki tingkat budaya pajak yang lebih tinggi dan dengan demikian tingkat kepatuhan yang lebih tinggi pula. Cummings, Martinez-Vasquez, McKee, dan Torgler (2009) menyimpulkan bahwa perbedaan lintas budaya dalam kepatuhan pajak disebabkan oleh persepsi wajib pajak terhadap administrasi perpajakan dan penilaian terhadap kualitas pemerintah.

Mempertimbangkan masih rendahnya rasio pajak di Indonesia yang diakibatkan masih rendahnya kepatuhan pajak, peneliti ingin mengetahui, faktor-faktor psikologis apa saja yang melatarbelakangi kesediaan wajib pajak dalam melaporkan dan membayar pajak khususnya pajak penghasilan. Berdasarkan kajian literatur yang dilakukan, peneliti bermaksud untuk menggali gagasan, pengetahuan dan pengalaman wajib pajak terkait dengan perilaku pajak yang mereka lakukan. Tujuan dari penelitian ini adalah untuk memperoleh pandangan dan pengalaman wajib pajak berkaitan dengan pajak penghasilan serta memahami faktor apa saja yang memengaruhi kesediaan wajib pajak melakukan pembayaran pajak.

\section{Metode Penelitian}

Untuk memperoleh pemahaman yang lebih baik mengenai sifat dan kualitas dari fenomena berdasarkan perspektif partisipan, penelitian ini menggunakan rancangan fenomenologi interpretatif (Willig, 2008). Dalam konteks penelitian ini, rancangan tersebut digunakan untuk menjelaskan perilaku dan pengalaman partisipan dengan menggali persepsi, pemahaman, dan sikap yang mendasari mereka melaksanakan perannya sebagai wajib pajak yang benarbenar mengalami persoalan pajak.

Teknik pengumpulan data dilakukan menggunakan semi-structured interview kepada empat orang wajib pajak yang bersedia untuk terlibat dalam penelitian ini, terdiri dari 3 orang laki-laki dan satu orang perempuan yang memiliki NPWP Pribadi juga bertanggung jawab terhadap NPWP Badan. Pemilihan sumber data mempertimbangkan karakteristik yakni merupakan wajib pajak orang pribadi sekaligus penanggungjawab badan usaha yang mereka jalankan dengan masa kepemilikian NPWP lebih dari 7 tahun. Diasumsikan sebagai aktor langsung dalam melaporkan dan membayarkan pajak memungkinkan adanya pengalaman yang berbeda dan pengetahuan yang lebih luas terkait pajak antar subjek.

Pertanyaan diberikan untuk mengetahui pemaknaan, pengetahuan, keyakinan atau sikap sebagai faktor yang mendasari 
kesediaan partisipan melaporkan dan membayarkan pajak. Dua pertanyaan utama dalam penelitian ini yakni "Bagaimana pengalaman Anda selama ini dalam membayar pajak?" dan "Konteks atau situasi apa saja yang biasanya memengaruhi Anda dalam membayar pajak?" diberikan untuk membiarkan partisipan menceritakan kisahnya sendiri maupun mengekspresikan pengalamannya. Dari setiap penelitian diawali dengan menghubungi wajib pajak dengan karakteristik yang sudah ditentukan untuk meminta kesediaan menjadi narasumber dalam penelitian serta tempat dan waktu yang disepakati untuk proses interview. Pelaksanaan proses interview kurang lebih satu jam untuk masing-masing narasumber. Data dianalisis mencakup proses menyoroti pernyataan, kalimat, atau kutipan penting yang memberikan pemahaman tentang bagaimana partisipan mengalami fenomena tersebut (Cresswell, 2007), dan selanjutnya dikembangkan tema dari kelompok makna pernyataan signifikan. Pernyataan dan tema yang dikembangkan dari kelompok makna kemudian digunakan untuk mengembangkan deskripsi yang dialami partisipan (deskripsi tekstur) dan deskripsi yang menggambarkan konteks yang memengaruhi pengalaman (deskripsi struktural). Dari deskripsi struktural dan tekstur yang terpisah ini kemudian digabungkan menjadi satu deskripsi terpadu.

\section{Hasil Penelitian dan Pembahasan}

Berdasarkan hasil analisis terhadap transkrip wawancara satu per satu dari setiap partisipan dan kemudian dikembangkan tema-tema umum yang relatif sama antar partisipan, peneliti menyajikan hasil dan analisanya dalam tema yang menjadi fokus penelitian.

\section{Pemaknaan mengenai Pajak Penghasilan}

Berdasarkan hasil wawancara diperoleh pemaknaan yang relatif sama mengenai pajak penghasilan Bapak A.M
(43 tahun) mengungkapkan bahwa pajak penghasilan adalah "kontribusi wajib dari pendapatan kita sebagai masyarakat terhadap negaranya" (komunikasi personal, 8 September 2018). Bapak A.A (45 tahun) menyatakan bahwa pajak penghasilan adalah "pungutan negara terhadap penghasilan kita maupun dari total transaksi yang diperoleh dalam pekerjaan" (komunikasi personal, 10 September 2018). Sedangkan Bapak I.M (46 tahun) dan Ibu L.A (40 tahun) berpendapat pajak penghasilan adalah retribusi wajib warga kepada negara yang dihitung dari pendapatan yang diperoleh.

Berdasarkan pendapat dari empat partisipan dapat disimpulkan bahwa membayar pajak penghasilan dipersepsi sebagai kontribusi wajib dari warga ataupun pungutan yang bersifat wajib oleh negara terkait dengan penghasilan ataupun pendapatan warganya. Dalam Undangundang No. 36 tahun 2008 bahwa Pajak Penghasilan $(\mathrm{PPh})$ adalah pajak yang dikenakan atas subjek pajak (orang yang menerima penghasilan) berkenaan dengan penghasilan yang diterima atau diperolehnya dalam suatu tahun pajak (diakses dari kemenkeu.go.id). Pemaknaan terkait pajak penghasilan yang dimiliki partisipan penelitian menunjukkan bahwa mereka memiliki pengetahuan yang cukup baik mengenai apa itu pajak penghasilan. Mereka juga memiliki kesadaran bahwa pajak penghasilan adalah kewajiban yang mengikat warga terhadap negaranya berkaitan dengan pendapatannya.

\section{Pengalaman dalam Pembayaran Pajak Penghasilan}

Persepsi mengenai pembayaran pajak penghasilan sangat berkaitan dengan bagaimana partisipan merasakan kemudahan maupun kesulitan dalam melakukan pelaporan maupun pembayaran pajak. Pengalaman yang dianggap mudah dalam membayar pajak, antara lain perubahan sistem dari manual menjadi online. Hal tersebut diperoleh melalui 
pernyataan Bapak A.A (45 tahun) bahwa "yang memudahkan sekarang sudah sistimnya online. ... Laporan tidak harus dianter lagi kan" (komunikasi personal, 10 September 2018). Partisipan yang lain berpendapat bahwa "dengan sistem online menjadi lebih mudah karena cepat, otomatis, transparan karena sistem pemotongan dari hasil pekerjaan dengan pihak lain menjadi transparan...tidak ada main mata dengan pegawai pajak" (Ibu L.A, 40 tahun, komunikasi personal, 1 Oktober 2018).

Pada sisi yang lain, partisipan menilai perubahan sistem dari manual ke online masih menyisakan cukup banyak persoalan yang dianggap sebagai kesulitan oleh wajib pajak. Hal ini terkait misalnya "cara pengisiannya masih rumit, bisa dikatakan tidak user-friendly" (Bapak A.A, komunikasi personal 10 September 2018) atau "bagi yang tidak memahami hal-hal teknis dalam pengisian pajak, pasti sulit...seperti saya, pusing dan takut salah, makanya suruh staf atau bayar orang lain saja" (Bapak I.M, 46 tahun, komunikasi personal 28 September 2018). Partisipan lain menjelaskan bahwa "kelebihan bayar pajak prosesnya agak panjang dan agak rumit tidak secara otomatis bisa diklaim" (Bapak A.M, komunikasi personal 8 September 2018).

Hal lain yang terkait dengan pengalaman pajak menurut partisipan berkaitan dengan masih lemahnya sosialisasi aturan perpajakan sehingga berakibat pada rendahnya pengetahuan dan kemampuan dalam pelaporan pajak. Misalnya pihak rekanan (mitra kerja) tidak mengetahui mana saja objek yang dikenakan pajak atau berapa besaran pajaknya. Bapak A.M menjelaskan bahwa "kadang pihak dinas instansi terkait, atau rekanan tidak semuanya mengetahui tentang aturan pajak yang kena $P P h$, dan $P P n$ atau yang kena PPh saja..ini juga jadi masalah ketika harus melaporkan pajaknya" (komunikasi personal 8 September 2018).
Berkaitan dengan situasi atau konteks apa yang memengaruhi partisipan dalam membayar pajak, seluruh partisipan menyatakan bahwa kesadaran dirinya sebagai wajib pajak. Ibu L.A menyatakan "sebagai warga negara kita kena aturan negara... ya bayar pajak" (komunikasi personal, 1 Oktober 2018). Pendapat yang serupa juga dinyatakan oleh bapak A.M bahwa "kita mengetahui secara sadar ada kebijakan dan aturan-aturan bayar pajak sebagai kewajiban sebagai warga negara" (komunikasi personal 8 September 2018). Sedikit berbeda dengan pendapat itu, Bapak A.A, menyatakan bahwa yang mendorong dirinya membayar pajak adalah "kesadaran bahwa semua pekerjaan dan kegiatan kita menggunakan fasilitas negara ... misalnya jalan" (komunikasi personal, 10 September 2018). Bapak I.M menyatakan bahwa situasi yang mendorong dia membayar pajak berkaitan dengan pengetahuan terkait pekerjaannya, "berkaitan pekerjaan dengan pemerintahan itu pasti sudah ada apa... aturannya dalam kontrak ... sudah tercatat gitu kan. Sebelum kegiatan berjalan pun itu pajaknya sudah mulai ditentukan, kita nanti ada kena pajak sekitar sekian \% atau berapa itu ada" (komunikasi personal 28 September 2018).

Dalam pandangan para partisipan, hal yang juga penting untuk mendukung kesadaran wajib pajak untuk tetap bersedia membayar pajak adalah pemberian penguatan dari aparatur pajak. Bapak I.M misalnya memberikan argumen bahwa, "pegawai pajak itu menjadi ujung tombak dalam memberikan pelayanan, SDM (sumber daya manusia) di kantor pajak tidak ada salahnya sekarang datang kepada kita supaya memastikan bahwa kita ini sudah bayar atau belum, mengerti atau tidak..." (komunikasi personal 28 September 2018). Bapak A.M menyoroti proses pemberitahuan dari kantor pajak yang menekankan pemberian sanksi daripada melakukan upaya preventif agar wajib pajak bisa tepat waktu. Menurutnya dalam komunikasi personal: 
"perusahaan dan kita itu daftar sebagai wajib pajak, itu secara otomatis kita memasukkan alamat, memasukkan email, nomor handphone... dan seterusnya.. jadi perlu pemberitahuan, ada informasi, .... rutin bahwa perusahaan ini belum melaporkan ... pajak bulanan, apalagi itu pajak tahunan ... selama ini kan paling ada juga surat, itu juga ketika sudah harus membayar denda sekian..." (8 September 2018).

Ibu L.A merasa bahwa "ketegasan dalam aturan tidak diikuti dengan sosialisasi yang memadai kepada semua pihak sehingga pihak yang bertransaksi atau bekerja sama tidak cukup paham jumlah pajak yang harus dibayarkan untuk sebuah jasa atau barang, dan siapa yang menanggungnya". Menurutnya hal itu bisa berakibat adanya kelebihan membayar pajak untuk sesuatu yang seharusnya tidak demikian atau bahkan pajaknya tidak terbayarkan. "Jika kelebihan bayar, mengurus restitusi menjadi urusan yang tidak mudah, ketika tidak terbayar, tibatiba ada surat pemberitahuan tentang denda". Hal itu dianggap karena lemahnya pelayanan dari aparatur untuk melakukan upaya pencegahan. Sedangkan Bapak A.A, melihat bahwa secara kompetensi, para pegawai pajak sudah sangat memadai, namun dalam masalah layanan, masih perlu ditingkatkan. Menurutnya "pendekatannya lebih humanis, yang tidak membuat kaku, dan yang simpel...cepat dan simpel" (komunikasi personal 10 September 2018).

Faktor lain yang dianggap sesuatu yang perlu namun belum cukup terpenuhi adalah terkait hak wajib pajak untuk mengetahui bagaimana uang pajak mereka dimanfaatkan oleh negara. Bapak I.M menyatakan bahwa "kita cuma lihat di televisi atau di media, pajak itu buat pembangunan, tapi tidak pernah dijelaskan, dipisahkan untuk apa saja.. kadang-kadang kita bertanya, ini apakah uang pajak itu betul-betul untuk infrastruktur, atau hanya untuk perjalanan dinas? itu yang harus dibedakan".
Sedangkan partisipan yang lain mengungkapkan:

"sampai saat ini ... menuntut pemahaman yang agak dilematis juga. Pada satu sisi mungkin sudah ada kebijakan dan aturan-aturan tertentu bayar pajak... kewajiban sebagai warga negara, tapi pada sisi lain sebagai warga negara sebenarnya berhak tahu juga bahwa pajak itu diperuntukkan atau dipakai untuk hal apa saja. Ini yang mungkin belum terlihat .. transparan dari proses penggunaan pajak itu sendiri. Walaupun misalnya informasinya bahwa ... pemasukan APBN tertinggi itu adalah dari dari pajak gitu. Tapi kami selaku user atau pelaku yang selama ini bayar pajak, itu tidak belum mendapatkan informasi yang detail tentang bahwa pajak itu penggunaannya untuk apa saja" (Bapak, A.M, komunikasi personal 8 September 2018).

Terkait dengan informasi pemanfaatan pajak, Bapak A.A. mengharapkan adanya transparansi dari pihak pajak mengenai penggunaannya "harus bisa betul-betul dipergunakan untuk kepentingan masyarakat ... dan khususnya untuk pelayanan dasar, untuk membantu kemajuan perusahaan”. Dengan kata lain, adanya harapan dari para wajib pajak bahwa informasi pemanfaatan pajak bisa menjadi umpan balik untuk mereka yang telah membayar pajaknya.

Berdasarkan hasil studi, bahwa pengalaman partisipan dalam pelaporan dan pembayaran pajak dipengaruhi faktor internal dan faktor situasional. Faktor internal lebih berkaitan dengan pengetahuan pajak meliputi pengetahuan teknis administrasi dan regulasi pajak serta pengetahuan mengenai bagaimana uang hasil pajak digunakan. Pengetahuanpengetahuan terkait pajak tersebut selanjutnya berpengaruh dalam mendorong kesadaran dan motivasi wajib pajak dalam membuat keputusan membayar pajak. Sedangkan faktor situasional berkaitan dengan hubungan wajib pajak dan pihak otoritas pajak yang diwujudkan melalui 
persepsi tentang layanan yang diberikan dan trust wajib pajak terhadap otoritas pajak.

\section{Pengetahuan Pajak}

Secara umum, keempat narasumber menyatakan bahwa perubahan sistem pajak yang semula menggunakan sistem laporan manual menjadi sistem elektronik membawa dampak yang positif meski masih memerlukan perbaikan. Sistem elektronik memudahkan dalam pembuatan laporan, dianggap lebih transparan dan mempercepat proses karena tidak harus datang ke kantor pelayanan pajak. Namun demikian, beberapa hal yang masih dianggap merupakan hambatan dalam pelaporan pajak adalah keterbatasan pengetahuan tentang regulasi dan istilah teknis dalam pajak, cara pengisian yang tidak bersifat "user-friendly", serta persepsi bahwa formulir yang harus diisi rumit dan kompleks.

Menurut partisipan, seringkali yang dipermasalahkan adalah kesadaran mereka sebagai wajib pajak. Padahal dengan membayar pajak, sudah merupakan bukti bahwa mereka sadar akan kewajiban mereka sebagai warga negara yang menggunakan fasilitas dari negara. Namun demikian, para partisipan berpendapat bahwa mereka berhak untuk memperoleh informasi bagaimana uang pajak yang telah dibayarkan digunakan. Pengetahuan yang bersumber dari ketersediaan informasi mengenai pemanfaatan hasil pajak untuk sebesar-besarnya kepentingan umum dan untuk manfaat yang dapat mereka rasakan langsung, akan mendorong kesadaran membayar pajak dengan semestinya. Partisipan berpendapat bahwa informasi mengenai pemanfaatan uang hasil pajak secara transparan, jelas, dan mudah dipahami oleh para wajib pajak akan dapat meningkatkan kesadaran bahkan mungkin menggugah para wajib pajak yang menghindari pajak.

Menurut Alm (2012), kesediaan untuk membayar pajak meningkat ketika wajib pajak memiliki pengetahuan tentang undang-undang dan aturan pajak. Dapat diasumsikan bahwa penilaian dan evaluasi yang melatarbelakangi kesediaan dan kemampuan warga untuk mematuhi aturan berdasar pada persepsi dan pengetahuannya mengenai konsep perpajakan. Pengetahuan pajak subyektif yaitu pemahaman orang pada umumnya tentang perpajakan, penting dalam memahami mengapa individu berperilaku sebagaimana yang mereka lakukan (Kirchler, 2007).

Undang-undang perpajakan dikritik karena terlalu rumit untuk dipahami sepenuhnya oleh wajib pajak biasa, karena istilah teknis yang tinggi. Dalam penelitian Lewis (1982) ditemukan bahwa pada akhir tahun 1970-an untuk memahami undangundang perpajakan di Inggris, diperkirakan pendidikan paling tidak 13 tahun diperlukan; di AS diperlukan sekitar 12.5 tahun, sedangkan di Australia diperkirakan 17 tahun (dalam Hofmann, Hoelzl, \& Kirchler, 2008). Mayoritas wajib pajak tidak memahami undang-undang perpajakan dengan benar sehingga mengeluh memiliki pengetahuan subjektif yang buruk, merasa tidak kompeten dan tidak berdaya dalam masalah pajak, dan merasa terkendala untuk mencari bantuan dari para ahli, terutama praktisi pajak (Sakurai \& Braithwaite, 2003). Untuk itu, hambatan yang dirasakan oleh para partisipan penelitian berkaitan dengan pengetahuan regulasi pajak, kurangnya kemampuan teknis dalam menggunakan layanan online dan kesulitan memahami formulir pajak yang dianggap rumit, penting menjadi pertimbangan otoritas pajak dalam mengedukasi wajib pajak agar memiliki literasi pajak yang memadai. Dengan memiliki literasi yang mencukupi terkait pajak, hal tersebut akan memengaruhi kesadaran dan kesediaan membayar pajak dengan benar.

Pengetahuan mengenai perpajakan, selain berkaitan dengan regulasi dan sistem perpajakan yang digunakan, juga berkaitan dengan informasi yang dimiliki oleh wajib 
pajak terkait bagaimana uang pajak dimanfaatkan. Temuan dalam penelitian ini menunjukkan bahwa informasi tentang bagaimana uang pajak yang dikumpulkan oleh pemerintahan dikelola dan dimanfaatkan untuk penyediaan fasilitas dan layanan publik masih menjadi sesuatu yang dipertanyakan wajib pajak. Informasi yang tersedia masih berupa bagian dari berita yang diperoleh dari media massa baik media cetak maupun elektronik. Sebagai bentuk timbal balik dari pemenuhan kewajiban membayar pajak, para pembayar pajak menuntut haknya berupa informasi yang secara resmi diberikan dengan bahasa yang mudah dipahami, sesuai fakta yang dirasakan manfaatnya oleh sebagian besar masyarakat dan penyajian yang detil mengenai uang pajak digunakan untuk apa saja. Partisipan masih merasakan belum terpenuhinya hak keadilan bagi wajib pajak atas informasi pemanfaatan uang hasil pajak secara transparan, jelas, dan sesuai yang dibutuhkan oleh wajib pajak.

Ketidakcukupan dan aksesibilitas informasi pemanfaatan sesuai kebutuhan dan pemaknaan wajib pajak patut diduga sebagai faktor yang menghambat kesediaan wajib pajak untuk kooperatif membayar pajak selama ini. Dalam banyak literatur, pengetahuan tentang penggunaan kontribusi dan penyediaan public goods memengaruhi kesediaan membayar pajak (Eichenberger \& Frey, 2002; HartnerTiefenthaler, Rechberger, \& Kirchler, 2013; Kirchler, Hoezl, \& Wahl, 2008; Wenzel, 2006). Holler, Hoelzl, Kirchler, Leder, dan Mannetti (2008) menemukan bahwa faktor relevan yang menentukan kesediaan untuk kooperatif dalam dilema public goods adalah pengetahuan warga tentang penggunaan kontribusi dalam penyediaan barang publik. Hal tersebut sangat erat kaitannya dengan persepsi mengenai keadilan terkait dengan kesetaraan yang dirasakan dari pajak yang dibayar serta barang dan layanan publik yang diterima (Torgler, 2005). Dengan kata lain ketika wajib pajak menganggap kontribusi mereka sebanding dengan penyediaan barang publik yang mereka ketahui atau ketidakpuasan dengan penyediaan barang publik oleh pemerintah maka semakin rendah kepatuhan membayar pajak (Hoffman, dkk. 2008).

\section{Persepsi tentang Layanan dari Otoritas Pajak}

Direktorat Jenderal Pajak yang berada dalam koordinasi Menteri Keuangan berperan dalam pengelolaan pajak. Secara umum, penilaian partisipan terhadap otoritas pajak dalam membuat sistem perpajakan dan melaksanakan regulasi pajak dipandang sudah sesuai tugas dan fungsinya. Beberapa hal perlu ditingkatkan dengan menyederhanakan sistem pelaporan dari wajib pajak. Namun dalam tingkat pelaksanaan, partisipan memandang masih adanya persoalan dalam layanan yang diberikan oleh para pegawai pajak sebagai ujung tombak terdepan otoritas pajak. Konsistensi layanan dari kantor pajak sangat bergantung pada individu pegawainya sehingga ketika terjadi pergantian pegawai, proses yang sedang berlangsung seolah-olah berulang kembali (tidak efisien karena bertele-tele). Selain itu, belum dirasakannya layanan yang berbasis kebutuhan dari wajib pajak sehingga tidak adanya upaya preventif atas kesalahan pelaporan melainkan seolah-olah menunggu kesalahan terjadi. Para partisipan berharap, para pegawai pajak dapat memberikan pendampingan dengan menempatkan wajib pajak sebagai mitra yang perlu informasi, edukasi, dan diberdayakan secara lebih baik. Dengan pola pembinaan yang tepat, wajib pajak akan terdorong untuk dapat melaporkan dan membayarkan pajak secara sukarela, bukan sekedar menghindari sanksi administrasi atau denda semata. Cara otoritas pajak memperlakukan para wajib pajak terkait hal-hal prosedural memainkan peran penting dalam memengaruhi kesediaan membayar pajak (Feld \& Frey, 2007). Secara prosedural terdapat dua komponen penting dalam perlakuan otoritas 
pajak terhadap pembayar pajak yakni bagaimana prosedur dilaksanakan dengan transparan dan jelas, serta yang kedua adalah perlakuan yang penuh hormat sebagai pihak yang bermitra.

Sebagaimana pada bidang administrasi publik lainnya, administrasi pajak di banyak negara juga mengalami perubahan menuju pendekatan yang lebih berorientasi pada layanan, termasuk di Indonesia. Partisipan dalam penelitian ini mengakui bahwa perubahan sistem pelaporan dan pembayaran pajak melalui sistem daring dinilai memudahkan dan mengurangi beban administrasi maupun emosional karena lebih efektif dan efisien dalam waktu melaporkan. Namun demikian pendampingan teknis baik melalui penyuluhan ataupun kemudahan layanan pelanggan secara tatap muka maupun melalui fasilitas daring (telepon dan web) tetap diperlukan.

Layanan yang berbasis kebutuhan dari wajib pajak perlu diupayakan secara konsisten mengingat dalam pelaporan SPT, wajib pajak masih menghadapi kendala teknis maupun abstraksi dari setiap item pada formulir yang kurang dipahami dengan baik. Tugas utama otoritas pajak harus berorientasi layanan melalui, misalnya, mendidik klien mereka, membantu mereka dalam pencatatan, meningkatkan kemudahan dalam pelaporan pajak, memberikan akses ke informasi, dan menjelaskan pilihan-pilihan (Braithwaite, 2009). Dengan meningkatkan kemampuan baik pengetahuan maupun keterampilan dalam administrasi pajak dapat dianggap sebagai upaya preventif terhadap munculnya kesalahan pelaporan yang berakibat pada pemberian sanksi atau denda.

\section{Trust kepada Otoritas Pajak}

Perubahan layanan yang lebih baik dari pegawai pajak, juga diyakini wajib pajak memengaruhi kepercayaan mereka kepada otoritas pajak. Peningkatan kualitas layanan berdasarkan pada keyakinan mengenai kemampuan dan keahlian otoritas pajak sebagai pihak yang kompeten dan dapat dipercaya dalam tugas mereka mengelola pajak. Demikian juga dengan transparansi dalam pemanfaatan uang hasil pajak merupakan salah satu hal yang mendorong kepercayaan warga terhadap pemerintahnya dalam hal ini otoritas pajak. Sebagai wajib pajak, partisipan mengharapkan keterbukaan mengenai untuk apa dan bagi siapa hasil pajak memberikan manfaat. Terpenuhinya hal yang dianggap sebagai hak mereka setelah menunaikan kewajibannya membayar pajak akan memenuhi rasa keadilan dan pada gilirannya memengaruhi keyakinannya bahwa pemerintah merupakan pihak yang dipercaya.

Persepsi layanan dari pihak otoritas pajak tidak hanya dipandang sebagai faktor yang dapat memfasilitasi kooperatif warga dengan pemerintahannya, tetapi juga sebagai upaya untuk meningkatkan kepercayaan dan keyakinan dalam administrasi publik, politik, dan pemerintahan (Heintzman \& Marson, 2005). Hal tersebut sejalan dengan penelitian Balliet dan Van Lange (2013) bahwa dampak layanan dari pihak otoritas yang dipersepsi anggotanya akan meningkatkan trust kepada otoritas dan pada gilirannya berpengaruh pada perilaku kooperatif dari warganya.

Dalam situasi dimana warga sebagai wajib pajak melihat diri mereka sebagai mitra pemerintah dan otoritas pajak dalam hubungan kooperatif, Feld dan Frey (2007) berpendapat bahwa kepatuhan pajak dapat ditingkatkan dengan mempertahankan hubungan yang baik antara pemerintah, otoritas pajak, dan pembayar pajak. Pemerintah dan otoritas pajak haruslah menjadi pihak yang dipercaya untuk tugas mengelola anggaran pajak dengan hemat dan menjawab kebutuhan warganya. Berdasarkan penelitian ini, partisipan memandang bahwa otoritas pajak dalam hal ini direpresentasikan oleh aparatur pajak sebagai pihak yang cukup kompeten dalam melakukan tugas dan fungsinya mengadministrasikan pajak. Beberapa hal yang masih perlu ditingkatkan adalah peran 
pembinaan dan mengedukasi wajib pajak tentang aturan perpajakan, penyederhanaan sistem dan kontrol atas penggunaan hasil pajak yang dilaporkan secara transparan kepada seluruh warga khususnya wajib pajak.

Levi, Sacks, dan Tyler (2009) menyatakan, keyakinan bahwa pemerintah dapat dipercaya mencerminkan penilaian bahwa pihak otoritas termotivasi untuk memenuhi janji-janji mereka dan melakukan apa yang benar untuk warga yang mereka layani, membuat kebijakan yang benar-benar bermanfaat bagi masyarakat mereka. Demikian pula dalam bidang pajak, pihak otoritas yang ditugaskan mengelola administrasi pajak harus menunjukkan kompetensi, kebajikan, integritas, dan keterbukaan/ kejujuran dalam menjalankan tugas dan fungsinya. Evaluasi kepercayaan tergantung pada penilaian dari kualitas kinerja pemerintah, dan kompetensi tenaga administratifnya. Pemerintah dan otoritas yang menyediakan layanan serta perlindungan yang ditujukan untuk meningkatkan kesejahteraan warga negara atau secara nyata mengembangkan kapasitas untuk melakukan hal itu, lebih memengaruhi munculnya rasa kerelaan warga untuk patuh dan kooperatif.

\section{Simpulan}

Dalam penelitian mengenai perilaku pajak, terjadi perubahan dalam memahami wajib pajak sebagai individu yang hanya mementingkan diri untuk memaksimalkan keuntungan pribadi bergeser pada pemahaman kepada individu yang memiliki rasa tanggung jawab kepada komunitas atau kelompoknya. Pada dasarnya tidak ada individu yang senang untuk membayar pajak karena pajak bersifat mengikat sebagai kontribusi wajib yang dipungut secara paksa dan disertai dengan ancaman hukuman bilamana tidak patuh. Namun, bukan berarti juga warga negara tidak bersedia menyumbangkan sebagian dari pendapatan mereka dalam menyediakan barang dan layanan publik untuk kesejahteraan bersama seluruh bangsa. Hampir tidak ada keraguan tentang nilai penting dari semua barang publik yang dibiayai dengan pajak. Namun, tentu ada keraguan besar tentang apakah anggaran pajak dikelola dengan benar dan digunakan untuk kesejahteraan umum. Asumsi tersebut yang melatarbelakangi perilaku wajib pajak dalam melaporkan dan membayarkan pajaknya dengan benar.

Penting kiranya mendudukkan otoritas pajak dan wajib pajak sebagai mitra yang bekerjasama dan mengejar tujuan yang sama bagi masyarakat, daripada melihatnya sebagai "polisi dan penjahat" dalam melaksanakan regulasi pajak. Untuk itu, memerhatikan variabel internal atau faktor psikologis diasumsikan lebih penting dalam membentuk kesediaan pembayar pajak untuk bekerjasama (Kirchler dkk., 2008). Variabel-variabel seperti pengetahuan wajib pajak tentang regulasi dan administrasi pajak, persepsi terhadap pemerintah terkait dengan layanan dan kepercayaan (trust) publik terhadap otoritas pajak perlu dipertimbangkan untuk mendorong kepatuhan sukarela dalam membayar pajak.

\section{Daftar Pustaka}

Allingham, M. G., \& Sandmo, A. (1972). Income tax evasion: A theoretical analysis. Journal of Public Economics, 1(3-4), 323-338.

Alm, J. (2012). Measuring, explaining, and controlling tax evasion: Lessons from theory, experiments, and field studies. International Tax and Public Finance, 19(1), 54-77.

Alm, J., Sanchez, I., \& deJuan, A. (1995). Economic and noneconomic factors in tax compliance. Kyklos, 48(1), 3-18.

Balliet, D., \& Van Lange, P. (2013). Trust, punishment, and cooperation across 18 societies: A meta-analysis. Perspectives on Psychological Science, 8(4), 363-379.

Becker, G. S. (1968). Crime and punishment: An economic approach. 
Journal of Political Economy, 76(2), 169-217.

Braithwaite, V. (2003). A new approach to tax compliance. In V. Braithwaite (Ed.), Taxing democracy. Understanding tax avoidance and tax evasion (pp. 1-11). Aldershot, UK: Ashgate.

Cummings, R. G., Martinez-Vazquez, J., McKee, M., \& Torgler, B. (2009). Tax morale affects tax compliance: Evidence from surveys and an artefactual field experiment. Journal of Economic Behavior \& Organization, 70(3), 447-457.

Dawes, R. M. (1980). Social dilemmas. Annual Review of Psychology, 31, 169193.

Eichenberger, R., \& Frey, B. S. (2002). Democratic governance for a globalized world. Kyklos, 55(2), 265288.

Feld, L. P., \& Frey, B. S. (2007). Tax compliance as the result of a psychological tax contract: The role of incentives and responsive regulation. Law \& Policy, 29(1), 102-120.

Hartner-Tiefenthaler, M., Rechberger, S., \& Kirchler, E. (2013). Justice perceptions and cooperation of citizens with the tax-authorities: The group engagement model of cooperation. Citizenship Teaching \& Learning, 8(2), 179-193.

Hofmann, E., Hoelzl, E., \& Kirchler, E. (2008). Preconditions of voluntary tax compliance: Knowledge and evaluation of taxation, norms, fairness, and motivation to cooperate. Journal of Psychology, 216(4), 209-217.

Hofmann, E., Hartl, Gangl, Tiefenthaler, \& Kirchler. (2017). Authorities' coercive and legitimate power: The impact on cognitions underlying cooperation. Frontiers in Psychology, 8, 1-15.

Heintzman, R., \& Marson, B. (2005). People, service and trust: Is there a public sector service value chain?
International Review of Administrative Sciences, 71(4), 549-575.

Holler, M., Hoelzl, E., Kirchler, E., Leder, S., \& Mannetti, L. (2008). Framing of information on the use of public finances, regulatory fit of recipients and tax compliance. Journal of Economic Psychology, 29(4), 597-611.

Hyun, J. K. (2006). Tax compliances in Korea and Japan: Why are they so different?. The Journal of The Korean Economy, 7(1), 135-153.

Kirchler, E. (2007). The economic psychology of tax behaviour. Cambridge: Cambridge University Press.

Kirchler, E., Hölzl, E., \& Wahl, I. (2008). Enforced versus voluntary tax compliance: The "slippery slope" framework. Journal of Economic Psychology, 29, 210-255.

Kogler, C., Batrancea , L., Nichita, A., Pantya, J., Belianin, A., \& Kirchler, E. (2013). Trust and power as determinants of tax compliance: Testing the assumptions of the slippery slope framework in Austria, Hungary, Romania and Russia. Journal of Economic Psychology, 34, 169-180.

Levi, M., Sacks, A., \& Tyler, T. (2009). Conceptualizing legitimacy, measuring legitimating beliefs. American Behavioral Scientist, 53(3), 354-375.

Maciejovsky, B., Kirchler, E., \& Schwarzenberger, H. (2007). Misperception of chance and loss repair: On the dynamics of tax compliance. Journal of Economic Psychology, 28(6), 678-691.

Mardiasmo. (2011). Perpajakan. Edisi revisi. Yogyakarta: Penerbit ANDI.

Mittone, L. (2006). Dynamic behavior in tax evasion: An experimental approach. The Journal of SocioEconomics, 35(5), 813-835.

Parks, C., Joireman, J., \& Van Lange, P. (2013). Cooperation, trust, and antagonism: How public goods are 
promoted. Psychological Science in the Public Interest, 14(3), 119-165.

Sakurai, Y., \& Braithwaite, V. (2003). Taxpayers' perceptions of practitioners: Finding one who is effective and does the right thing?. Journal of Business Ethics, 46(4), 375387.

Torgler, B. (2005). Tax morale and direct democracy. European Journal of Political Economy, 21(2), 525-531.

Van Lange, P. A., Balliet, D., Parks, C. D., \& Van Vugt, M. (2014). Social dilemmas: The psychology of human cooperation. Oxford: Oxford University Press.

Wenzel, M. (2006). A letter from the tax office: Compliance effects of informational and interpersonal Justice. Social Justice Research, 19(3), 345364.

Willig, C. (2008). Introducing qualitative research in psychology. New York: Open University Press.

Undang-Undang Republik Indonesia Nomor 36 Tahun 2008 tentang Perubahan Keempat atas UndangUndang Nomor 7 Tahun 1983 tentang Pajak Penghasilan. Diakses tanggal 18 Januari 2019 dari https://jdih.kemenkeu.go.id/fullText/20 08/36TAHUN2008UU.htm
Undang-Undang Republik Indonesia Nomor 28 Tahun 2007 tentang Perubahan Ketiga Atas UndangUndang Nomor 6 Tahun 1983 tentang Ketentuan Umum dan Tata Cara Perpajakan. Diakses tanggal 18 Januari 2019 dari http://www.dpr.go.id/dokjdih/documen t/uu/UU_2007_28.pdf).

CNN Indonesia (2019, 2 April). Waktu Berakhir, Target Laporan SPT Pajak Tercapai 71 Persen. Diakses dari https://www.cnnindonesia.com/ekono mi/20190402140750-532382895/waktu-berakhir-target-laporanspt-pajak-tercapai-71-persen).

Tempo.Co (2017, 20 Juli). Kepatuhan Pajak di Indonesia masih rendah. Diakses dari https://bisnis.tempo.co/read/893001/ke patuhan-pajak-di-indonesia-masihrendah/full\&view=ok) 